\author{
Ewelina Bajer \\ Wydział Filologiczny \\ Uniwersytet w Białymstoku \\ e-mail: evelinabajer@gmail.com
}

\title{
Terapia słowem - „opowiedziane malarstwo” Alfreda Kubina
}

Alfred Kubin to jeden $\mathrm{z}$ nieco zapomnianych przedstawicieli tzw. austriackiej awangardy przełomu XIX i XX wieku. Zazwyczaj mówi się o nim w odniesieniu do innych tworzących wówczas artystów, mniej lub bardziej związanych z nurtem ekspresjonistycznym, takich jak: Wassily Kandinsky, Paul Klee, Oskar Kokoschka, Otton Wagner czy Egon Schiele. Kubin kojarzony jest również z monachijską grupą Neue Künstlervereinigung München [Nowe Stowarzyszenie Artystyczne]. Jednakże w 1911 roku malarz wraz z Wassilym Kandinskym, Franzem Marcem oraz Gabriele Münter odchodzą ze Stowarzyszenia i zakładają własną grupę Der Blaue Reiter [Błękitny Jeździec], którą historycy sztuki uznają za najważniejszą strukturę artystyczną w Niemczech przed wybuchem Pierwszej Wojny Światowej ${ }^{1}$. Stopniowo Kubin uwalnia się spod wpływów Paula Klee, zrywa z malarstwem abstrakcyjnym, lecz mimo to wciąż pozostaje pod wrażeniem prac Lyonela Feiningerema. Studiując obrazy Kubina można w nich dostrzec również nieskrywane inspiracje dziełami Féliciena Ropsa, Jamesa Ensora, Edwarda Muncha, Hansa Baldunga Griena, a zwłaszcza Francisco Goi, stąd też wziął się pseudonim malarza, który nazywany był „austriackim Goyą”. W ewolucji twórczej artysty wyraźnie widać, iż we wczesnym okresie Kubin bardziej niż malarstwem zajmował się grafiką. Jak twierdzi Peter Assmann, „na początku lat

\footnotetext{
1 Kalendarium życia i twórczości Alfreda Kubina, oprac. M. Oberchristl, M. Rydiger, w: Mroczna strona wyobraźni - sztuka Alfreda Kubina, przeł. na ang. J. Tayla-Kucia, przeł. na pol. J. Czudec, red. T. Leśniak, Kraków 2008, s. 132.
} 
dwudziestych [...] uchodził za jednego z najbardziej interesujących rysowników swojego pokolenia, cieszył się międzynarodową sławą, nie ograniczającą się już wówczas wyłącznie do niemieckiego obszaru kulturowego" ${ }^{2}$. Zdaniem Jana Gondowicza wczesne prace Kubina nawiązywały do popularnych szesnastowiecznych naddunajskich grafik, gotycyzmu Caspara Davida Friedricha oraz symbolizmu Alfreda Rethela i Maxa Klingera, którego Kubin uważał za największego żyjącego artystę ${ }^{3}$. To właśnie za sprawą akwaforty Klingera, zatytułowanej Paraphrase über den Fund eines Handschuhs, Kubin wpada w trwający do 1903 roku szał twórczy. W tym brzemiennym okresie kreśli też szereg szkiców zainspirowanych powracającymi, sennymi wizjami, a także eksperymentuje z różnorodnymi technikami rysunku. Według Jacka Purchly szkice Kubina przywodzą na myśl dzieła największych grafików europejskich, takich jak Bosch, Dürer czy Ensor ${ }^{4}$. Jednakże początkowo prace Kubina nie cieszyły się zbytnią estymą, zwłaszcza w kręgach niemieckiej Secesji. Gondowicz, analizując czarny humor obecny w dziełach Kubina zauważa, że „[e]steci z miesięcznika «Pan» ignorowali go za brak wyrafinowania, redaktorzy niemniej sławnego miesięcznika «Jugend» - za niedostatek wdzięku, a satyrycy z «Simplicissimusa» - za wyprane z dowcipu czarnowidztwo" ${ }^{5}$. Również zorganizowana w 1902 roku pierwsza samodzielna wystawa Kubina w prestiżowej galerii Paula Cassirera w Berlinie kończy się fiaskiem. Zarówno krytycy, jak i publiczność są zniesmaczeni eksponowaniem pornografii oraz "pławieniem się w patologicznych fantazjach" ${ }^{6}$. Prawdziwe poważne sukcesy artysta osiągnie niemal dekadę później. W latach 30. XX wieku jego twórczość zostaje zdefiniowana przez nazistów jako entartete Kunst (sztuka zdegenerowana). Hitler, przemawiając w Norymberdze, obiecał narodowi niemieckiemu, iż rozprawi się z wszelką twórczością, która będzie znacząco odbiegać od realizmu:

Dla kubizmu, dadaizmu, futuryzmu, impresjonizmu i tym podobnych kierunków nie ma miejsca wśród narodu niemieckiego. Wszystkie te pomysły nie są ani staromodne, ani nowoczesne. To tylko udawana gadanina ludzi, którym Bóg poskąpił prawdziwego talentu artystycznego [...]. Od tej pory będziemy prowadzić bezwzględną wojnę, aby wykorzenić elementy, które podkopują naszą kulturę ${ }^{7}$.

2 P. Assmann, Alfred Kubin - obrazy fantastyczne, w: Mroczna strona wyobraźni..., s. 9.

3 Por. J. Gondowicz, Olśniony mrokiem, w: Mroczna strona wyobraźni..., s. 27.

4 Por. J. Purchla, Alfred Kubin, czyli mroczna strona wyobraźni, w: Mroczna strona wyobraźni..., s. 7.

5 J. Gondowicz, Olśniony mrokiem, s. 32.

6 Kalendarium życia i twórczości Alfreda Kubina, s. 130.

7 Cyt. za A. Rydell, Bezcenne. Naziści opętani sztuka, przeł. W. Łygaś, Poznań 2015, s. 59. 
Co ciekawe, organizowane przez Josepha Goebbelsa, ówczesnego ministra propagandy III Rzeszy Die Ausstellung Entartete Kunst [Wystawy sztuki zdegenerowanej] przyciągały znacznie więcej gości, niż ekspozycje przedstawiające czystą, aryjską, prawdziwie narodową sztukę, prezentowaną w Haus der Deutschen Kunst. Do malarzy „zakazanych” oprócz Kubina zaliczono wielu pokrewnych mu twórców, takich jak: Ernst, Chagall, Kandinsky, Klee, Kirchner, Dix czy dobry przyjaciel „austriackiego Goi” - Franz Marc ${ }^{8}$. Stosunek Kubina do nowej władzy cechowała wyraźna niechęć, potęgowana faktem, iż żona artysty, Hedwig Gründler, była pół-Żydówką. Kubin stopniowo tracił zlecenia, spora część książek, które ilustrował, znalazła się na czarnej liście sporządzonej przez Krajową Izbę Książki w Berlinie. Dzięki swojej apolitycznej postawie podczas rządów NSDAP po wojnie malarz cieszył się szacunkiem, zwłaszcza wśród młodych austriackich artystów, którzy czerpali inspirację $\mathrm{z}$ jego dzieł.

Aktualnie historycy sztuki mają spory problem z przyporządkowaniem twórczości Kubina do jednego, określonego nurtu. Malarz oscyluje między symbolizmem a ekspresjonizmem, niektórzy zaś widzą w nim prekursora surrealizmu. Jak trafnie zauważa jeden $\mathrm{z}$ badaczy zgłębiających spuściznę artysty: „Nie bez powodu tajemniczą, pełną sprzeczności, trudną do rozwikłania sytuację określa się w języku niemieckim słowem kubinesk, wywodzącym się z doświadczenia jego sztuki" 9 .

Kubin w swoich obrazach kreował różnorodne, wielowymiarowe światy. Artysta eksperymentował z wieloma technikami, na przykład posługiwał się specjalną techniką wtryskową. Prace malarza budziły szereg kontrowersji, ponieważ zawierały elementy erotyzmu, pornografii, okrucieństwa czy frenezji, co $\mathrm{w}$ tamtych czasach było całkowicie niezgodne $\mathrm{z}$ gustami niemieckiego mieszczaństwa. Warto również zwrócić uwagę na swoistą literackość dzieł "czarownika z Zwickledt" ${ }^{10}$. Kubin obficie czerpał nie tylko z kanonu mistrzów, interesowały go zwłaszcza sagi i baśnie. Malarz przykładał dużą uwagę do tytułów swoich prac, które niemal zawsze dawały odbiorcy możliwość wielorakich interpretacji. Jego obrazy były niejako mozaiką wielu opowieści. Zdaniem Jacka Purchly, „przesiąknięte lękami i fobiami [...] znakomicie oddają kafkowskiego ducha Europy Środka u progu XX wieku. Ta Europa bowiem to nie tylko kwestia wyobraźni - to trauma i ambiwalencja" ${ }^{11}$.

\footnotetext{
8 Por. tamże, s. 67.

9 P. Assmann, Alfred Kubin - obrazy fantastyczne, s. 10.

10 "Czarownik z Zwickledt" to kolejny pseudonim Kubina, wywodzący się od nazwy zamku w Zwickledt w Górnej Austrii, który artysta nabył wraz z żoną w 1906 roku.

11 J. Purchla, Alfred Kubin, czyli mroczna strona wyobraźni, s. 8.
} 
Kubin przeżywał także osobiste traumy. Kiedy w 1907 roku umiera jego apodyktyczny ojciec, malarz doświadcza kolejnego załamania nerwowego. Wraz z przyjacielem, pisarzem i dramaturgiem Frizem Herzmanovskym wyjeżdża do Włoch. Wyprawa daje pożądany skutek, gdyż po powrocie dorobek artysty, dotychczas składający się z szkiców, grafik, litografii i obrazów, zostaje powiększony o dość nietypową pozycję literacką. Kubin w dwanaście tygodni tworzy powieść fantastyczną, którą zdobią pięćdziesiąt dwie grafiki jego autorstwa. Po tamtej stronie to antyutopijna książka pełna mroku, zapisanych koszmarów sennych i pierwiastków antynatalizmu, lecz przede wszystkim trzeba postrzegać ją jako owoc pogłębiającej się choroby psychicznej debiutującego pisarza. W założeniu autora powieść stanowiła substytut czy też rodzaj panaceum - tymczasowej niemocy twórczej. Rozstrojony nerwowo Kubin, nie mogąc malować, poddał się osobliwej psychoterapii: mianowicie zaczął pisać, niejako „opowiadać” swoje malarstwo. Kreowanie fabuły pozwoliło mu na oczyszczenie, było czymś w rodzaju tak potrzebnego wówczas katharsis. Walter Hilsbecher, badający terapeutyczne właściwości słów, stwierdza:

Pisanie jest odpowiedzią, choć tylko odpowiedzią częściową, na całą rzeczywistość - a cała rzeczywistość nie jest ani pogodna, ani piękna [...]. Jesteśmy raczej wystawieni na nieprzerwaną nawałnicę wrażeń, które nas pustoszą. Stan chaosu w nas jest permanentny - a my wytrzymujemy go tylko dzięki pewności, że na dnie wszelkiego chaosu leży możliwość kształtu, na dnie wszelkiego niepokoju - spokój. Utwierdzamy się w tej pewności „kształtując”12.

Krótko po publikacji w 1909 roku powieść Kubina cieszyła się sporym zainteresowaniem, zdobywając m.in. entuzjastyczne recenzje Maxa Broda, wydawcy i samozwańczego realizatora testamentu Franza Kafki. Niestety dziś zarówno sam autor, jak i jego praca znajdują się poza kręgiem zainteresowań historyków literatury, przebywają gdzieś na peryferiach, mówiąc nieco kolokwialnie - „wypadli z literackiego obiegu”. Zważywszy na ten fakt wskazane jest przybliżenie krótkiego biogramu artysty, co z pewnością pozwoli choć w minimalnej części zrozumieć źródło jego obsesji, powracających fobii oraz fascynacji.

Alfred Kubin przyszedł na świat w 1877 roku w Litomierzycach, małym mieście leżącym na terenie północnych Czech. Już jako dziecko odczuwał "osobliwy pociąg do przesady i fantastyki" ${ }^{13}$. W swojej autobiografii, cha-

12 W. Hilsbecher, Tragizm, absurd i paradoks. Eseje, Warszawa 1972, przeł. S. Błaut, s. 160-162.

13 A. Kubin, Demony i nocne zjawy. Autobiografia, w: tegoż, Po tamtej stronie, przeł. A.M. Linke, Warszawa 1980, s. 259. 
rakteryzując pierwsze, dziecięce rysunki, pisał: „Roiły się od czarowników, od komicznych lub strasznych stworzeń, ukazywały pejzaże całe $\mathrm{z}$ ognia słowem zawarty już był w nich w zarodku cały późniejszy Kubin"14. Kiedy malarz miał zaledwie dziesięć lat, na suchoty zmarła jego ukochana matka, pianistka, z którą dzielił pewien pułap artystycznej wrażliwości. Chłopiec stał się niemym świadkiem jej agonii oraz bezgranicznej rozpaczy ojca, który „chwyciwszy z łóżka długie zwłoki wynędzniałej żony, biegał tak po całym mieszkaniu, płacząc i jakby wołając o pomoc" ${ }^{15}$. Zgon kobiety w znacznym stopniu przyczynił się do niepokojącej fascynacji śmiercią, którą odczuwał nastoletni Kubin. Twórca, wspominając młodzieńcze lata, stwierdził:

Palącą ciekawość wzbudzało we mnie także wiele innych spraw. Na przykład zwłoki. Rybak Hölzl, mój opiekun, grabarz i w ogóle geniusz świata, wyciągał dość często z jeziora rozkładające się ciała, nie brakło bowiem nieostrożnych, którzy znajdowali śmierć w wodzie. Stąd właśnie zrodziło się moje gwałtowne zainteresowanie podobnie straszliwymi scenami. Wypadki śmierci były mi niepojęte i zdumiewające. Jak to się dzieje? Przestaje się widywać znajomych mężczyzn, kobiety i dzieci, podobno zachorowali; po dłuższej lub krótszej przerwie wolno potem wejść do ich mieszkania, i leżą tam sztywni, znieruchomiali i żółci: nieżywi. Obserwowałem też, co się dzieje u rzeźnika i rakarza, ale już raczej z zimnym, wyraźnym zaciekawieniem, a nie z demoniczną rozkoszą moich wcześniejszych lat ${ }^{16}$.

Niezdrowa adoracja śmierci, połączona z początkami depresji, zaważyła na podjęciu decyzji o samobójstwie. W 1896 roku Kubin, chcąc położyć kres swemu, jak sądził, „bezużytecznemu istnieniu” 17, z rewolwerem w kieszeni udał się na grób matki. Po latach, gromadząc retrospekcje i tworząc swą artystyczną biografię, w następujący sposób opisał to doświadczenie:

Przyłożywszy lufę do prawej skroni, na której według tablicy anatomicznej zrobiłem zadrapanie szpilką, by nie chybić mózgu, pociągnąłem za cyngiel. Ale zardzewiała stara broń zawiodła, a nacisnąć powtórnie zabrakło mi męstwa zrobiło mi się haniebnie mdło ${ }^{18}$.

Po nieudanej próbnie samobójczej Kubin całkowicie poświęcił się sztuce. Włoski psychiatra i kryminolog Cesare Lombroso, badając przypadki obłąkanych artystów, zauważył: „Zdarza się często, że ludzie obojętni pierwej

14 Tamże, s. 259.

15 Tamże.

16 Tamże, s. 261-262.

17 Tamże, s. 265.

18 Tamże. 
wobec sztuki w czasie choroby zaczynają rysować i właśnie najgorliwiej rysują $\mathrm{w}$ okresie najsilniejszego jej rozwoju" ${ }^{19}$. Cierpiący na postępującą depresję, nękany przez powracające czarne myśli początkujący malarz, artystycznego rzemiosła uczył się pod kierunkiem Ludwiga Schmitta-Reutteda, godzinami rysując akty oraz głowy. Studiował w Monachium, gdzie wraz z przyjaciółmi wiódł żywot na wzór Cyganerii Henriego Murgera ${ }^{20}$. Kubin codziennie bywał w kawiarni „Elite” przy Schelingstrasse, gdzie do białego rana dyskutowano o sztuce, artystach, nowych, ważnych prądach. Uczestniczył również w wolnym stowarzyszeniu Sturmfakel [Pochodni bojowej], głoszącym groteskowy postulat ukrócenia indywidualizmu w sztuce. Do tego dołączyła fascynacja Starą Pinakoteką, a także dziełami niezwykle modnego wśród niemieckiej bohemy Arthura Schopenhauera. Kubin, stale cierpiący na natłok wizji malarskich, które uporczywie domagały się urzeczywistnienia, oczarowany kolekcją obrazów i geniuszem Bruegla Starszego, przemierzał sale muzeów Wiednia i Paryża, poszukując wciąż nowych artystycznych podniet. „Demoniczny rozmach i siła” - to, zdaniem Kubina, charakteryzowało prawdziwe, święte, osobliwe, szaleńcze malarstwo. Artysta mawiał, że rządzi nim tajemna moc, która wyczarowuje w jego umyśle „dziwaczne zwierzęta, domy, pejzaże, groteskowe i straszne sytuacje” ${ }^{21}$, tworząc zaklęty świat. Wkrótce pojawiły się pierwsze sukcesy, wystawy, znaczna rozpoznawalność oraz... kolejne załamanie nerwowe, które zaowocowało powstaniem Po tamtej stronie.

Nadwrażliwy Kubin po śmierci ojca i chorobie żony popadł w stan twórczej hibernacji. Pełen pasji, a zarazem dojmującego smutku, pragnął tchnąć życie w powracające wizje, jednak przyzwyczajona do pędzla ręka uparcie odmawiała mu posłuszeństwa; diagnoza: niemoc twórcza. Pogrążony w inercji artysta postanowił znaleźć alternatywę, która rychło przybrała formę zaczarowanej opowieści. Kubin w następujący sposób wyjaśniał genezę jedynej w swoim dorobku książki:

Nie byłem w stanie narysować powiązanych rozsądnych kresek. Przestraszony stałem przed tym nowym fenomenem [...]. Aby więc coś robić i jakoś się wyładować, zacząłem sam wymyślać i notować dziwaczną opowieść. I oto napłynęły pomysły w nadmiarze, dniem i nocą napędzając mnie do pracy, tak że już po dwunastu tygodniach moja powieść fantastyczna Po tamtej stronie była ukończona ${ }^{22}$.

\footnotetext{
19 C. Lombroso, Geniusz i obłakanie, przeł. J.L. Popławski, Warszawa 1987, s. 195.

20 Por. H. Murger, Sceny z życia cyganerii, przeł. T. Żeleński (Boy), Warszawa 1957.

21 A. Kubin, Demony i nocne zjawy. Autobiografia, s. 271.

22 Tamże, s. 279-280.
} 
Zdaniem niektórych badaczy powieść Kubina wywarła poważny wpływ na literaturę niemieckiego obszaru językowego, jednocześnie stając się ,,jednym z kamieni milowych $\mathrm{w}$ rozwoju prozy europejskiej XX wieku" ${ }^{23}$. Jednak dzieło to funkcjonuje jedynie na obrzeżach niemieckiego ekspresjonizmu, w cieniu takich sław, jak Robert Musil czy Oskar Kokoschka. Powszechnie książka ta, wymykając się wszelkim klasyfikacjom gatunkowym, figuruje pod hasłem: „dziwotwór literacki”, będący przykładem korespondencji sztuk, o której pisze Alina Biała ${ }^{24}$. Z kolei Paweł Huelle traktuje ją jako dokument psychografii, będący zapisem wędrówki „w głąb własnej jaźni, wiwisekcyjnej rejestracji przeżyć, [...] niezwykłych, często przerażających wizji" 25. Sam autor nazywał Po tamtej stronie powieścią fantastyczną, która odzwierciedla „wariacki świat” z początku XX wieku, niezwykle trafnie oddając niepokoje towarzyszące człowiekowi wkraczającemu w nowe stulecie. Jednocześnie, o czym była mowa wcześniej, dzieło to konkretyzuje niespełnione, natrętne obrazy nękające Kubina, które ten, w akcie pewnej desperacji, przepuścił przez czysto literackie medium. Jak trafnie zauważa Stefan Lichański:

To już nie literatura zainspirowana przez malarstwo jak np. powieść Przybyszewskiego Krzyk, której pomysł nasunął pisarzowi obraz Muncha pod tym samym tytułem. To zapis wizji malarskich, wiązanych przy pomocy literackiej „konferansjerki" w całość przypominającą z grubsza to, co w języku poetyki opisowej nazywa się powieścią ${ }^{26}$.

Oryginalna, synkretyczna forma powieści idealnie odpowiadała estetycznemu nastawieniu epoki. Lichański zwraca uwagę, iż w okresie modernizmu nieraz postulowano stworzenie czegoś na kształt arcysztuki, będącej syntezą różnych gatunków, jak choćby wydana w 1904 roku teka drzeworytów Wiersze bez słów, autorstwa Wassilego Kandinskiego ${ }^{27}$. Po tamtej stronie traktowano jako powieść awangardową, pełną treści podświadomych i ukrytego symbolizmu. Należy pamiętać, iż prawie dziesięć lat wcześniej, w 1899 roku, Sigmund Freud opublikował Objaśnianie marzeń sennych, rewolucjonizując teorię psychoanalityki oraz dając początek popularnej obecnie teorii psychoanalizy. Kubin znał teksty Freuda, jednakże w późniejszym okresie bliższe mu było stanowisko Carla Gustava Junga. Tym samym pisarskie dzieło malarza idealnie wpasowało się $\mathrm{w}$ najnowsze wówczas trendy, eksploatując strefę pod-

\footnotetext{
23 S. Lichański, Alfreda Kubina Państwo Snu, w: A. Kubin, Po tamtej stronie, s. 5.

24 Por. A. Biała, Literatura i malarstwo: korespondencja sztuk, Warszawa-Bielsko Biała 2009.

25 P. Huelle, Postowie do A. Kubin, Po tamtej stronie, s. 271.

26 Tamże, s. 8.

27 Por. S. Lichański, Alfreda Kubina Państwo Snu, s. 7.
} 
i nadświadomości. Przestrzeń powieści nieustannie przenika popęd śmierci (Tanatos), który niejako zapowiada finalną zagładę.

Po tamtej stronie stanowi unikalny przykład „opowiedzianego malarstwa". Kubin, kreując nastrój, posiłkuje się sugestywną paletą barw, zazwyczaj w ciemnej, zimnej tonacji:

Co w ojczystym kraju paradowało w bogactwie barw, tutaj było przytłumione, wybladłe. Podczas gdy w większości pejzaży niebieskość powietrza z żółtością gruntu tworzy dominantę, inne zaś barwy zdają się tylko w nie powprawiane, tutaj dominowała szarość i brązy. Brak było najpiękniejszego: kolorowości ${ }^{28}$.

Mroczna aura spowijająca powieściową rzeczywistość bliska jest obrazowaniu Franza Kafki, u którego nie odnajdziemy innych kolorów, niż czerń, biel i szarość. Autor Zamku, podobnie jak Kubin, niejednokrotnie czerpał natchnienie z wizji oraz snów. W Dziennikach Kafka przyznaje: „Moje historie są pewnego rodzaju zamykaniem oczu [...]. Sen odsłania rzeczywistość, której nie odpowiada wyobrażenie. Na tym polega groza życia - to, co nas przejmuje w sztuce" 29 .

Państwo Snu, gdzie toczy się akcja powieści, to naznaczona absurdem oniryczna kraina, w której odnajdziemy również odwołania do cenionych przez autora mistrzów, takich jak Rembrandt, Ruysdael, Bruegel, Altdorfer czy Grünewald i jego sugestywny obraz Siedem grzechów śmiertelnych pożera Baranka Bożego. Sztuka w antyutopii Kubina traktowana jest nad wyraz marginalnie, obrazy to jedynie przedmioty użytkowe. Z wyjątkiem prac wspomnianych artystów galerie pełne są kiczu i tanich podróbek, określonych jako "cienko malowane płótna, dziesiąta woda po kisielu Holandii" ${ }^{30}$. Pełne tandety Państwo Snu stanowi rodzaj ostatniego bastionu, który opowiedział się przeciw nowoczesności. Można mówić tu o przestrzeni, która mimowolnie przekształca się $\mathrm{w}$ relikt, w pewnym stopniu nawiązujący do złotych czasów spokojnego wówczas imperium Habsburgów. Władca kraju, Klaus Patera, zarządził, aby jego agenci importowali jedynie stare, europejskie domy. Mieszkańcy mają obowiązek nosić starodawne ubrania, nawiązujące do poprzedniej epoki:

Pierwsze, co nam się rzuciło w oczy: stroje obywateli [...] były zupełnie przestarzałe. U tak zwanych "ludzi wytwornych" było to szczególnie widoczne.

\footnotetext{
28 A. Kubin, Po tamtej stronie, s. 60.

29 F. Kafka, Dzienniki 1910-1923, przeł. J. Werter, Londyn 1993, s. 57.

30 A. Kubin, Po tamtej stronie, s. 82.
} 
- Ci ludzie donaszają odzież swoich rodziców i dziadków! - rzekłem ubawiony do żony. Zupełnie niemodne, wygięte cylindry, kolorowe surduty, płaszcze $z$ pelerynką - tak byli poubierani panowie. $W$ krynolinach i dziwnie staroświeckich fryzurach, w czepeczkach i szalach - paradowały panie. Wyglądało to jak karnawałowa maskarada.

[...] po kilku dniach byliśmy zmuszeni się przystosować. [...] nosiłem z godnością wcięty surdut, głęboko wyciętą kamizelkę w kwiatki i wysoki kołnierzyk („,Vatermörder") a la $1860^{31}$.

Pełen futurystycznych fobii dyktator żywi „niezmierną odrazę do wszystkiego w ogóle, co ma związek z postępem [...] do wszystkiego, co postępowe zwłaszcza w dziedzinie wiedzy" ${ }^{32}$. Kraina snu pełniła rolę schroniska przyjmującego renegatów niezadowolonych ze stanu nowoczesnej kultury ${ }^{33}$. Schroniska wyjątkowo mrocznego, ponieważ obywatelom nie dane było cieszyć się promieniami słońca: „kilka razy [...] padło z horyzontu na nasze miasto parę ukośnych smug światła, lecz nigdy, nigdy nie doszło do zwycięskiego przedarcia się słońca" ${ }^{34}$.

Atmosfera tego niepokojącego, a zarazem hipnotyzującego i zaczarowanego miejsca mogła zainspirować także niektórych polskich twórców, takich jak Schulz czy Witkacy, którzy mieli okazję poznać popularną wówczas sztukę Kubina. Schulzowskie Sanatorium pod Klepsydra opowiada o niezwykłym uzdrowisku, położonym $\mathrm{w}$ innym wymiarze czasowym. To także przestrzeń owiana aurą groteskowej alogiczności. Przewrotna nazwa tego domu dla kuracjuszy bynajmniej nie wróży powrotu do zdrowia. Symbolika klepsydry widniejącej na nekrologach $\mathrm{z}$ jednej strony odnosi się do nieuchronnej śmierci, z drugiej zaś „obrotowość klepsydry piaskowej czy wodnej sugeruje możliwość powrotu sytuacji wyjściowej [...] Otrzymujemy więc zjawisko pozornie ograniczone wyznacznikami czasowymi, a w gruncie rzeczy powtarzalne" ${ }^{35}$. U Schulza realność sanatorium zostaje zakwestionowana przez wszechobecny sen:

- Teraz wszyscy śpią. Gdy Pan Doktór wstanie, zamelduję pana.

- Śpią? Przecież jest dzień, daleko jeszcze do nocy...

- U nas ciągle śpią, Pan nie wie? [...] Zresztą tu nigdy nie jest noc $[\ldots]^{36}$.

\footnotetext{
31 Tamże, s. 65.

32 Tamże, s. 19.

33 Por. tamże.

34 Tamże, s. 60.
}

35 W. Kiedacz, Sanatorium pod Klepsydra - proza Schulza i wizje Hasa, w: Studia o prozie Brunona Schulza, red. K. Czaplewa, Katowice 1976, s. 144.

36 B. Schulz, Sanatorium pod Klepsydra, w: B. Schulz, Opowiadania. Wybór esejów i listów, oprac. J. Jarzębski, Wrocław-Warszawa-Kraków 1998, s. 264. 
W Sanatorium pod Klepsydra Calderonowski motyw życie-snem funkcjonuje na zasadzie odwrotności rozpatrywanej $\mathrm{w}$ kategoriach snu-agonii. Jerzy Speina zauważa wyraźną analogię między Sanatorium a Po tamtej stronie. Badacz twierdzi, iż w przypadku tego opowiadania Schulz mógł czerpać z utworu Kubina, niejako adaptując pomysł Państwa Snu:

Do Państwa tego, tak jak do Sanatorium, przyjeżdża się koleją trzeciej klasy, ruszającą $\mathrm{z}$ bezludnego peronu [...] życie oparte jest tam na zasadach odbiegających od naszych potocznych przyzwyczajen, zasadach przypominających sen ${ }^{37}$.

Zarówno Sanatorium, jak i Perła, stolica antyutopii Kubina, to przestrzenie labiryntowe, pełne zakamarków, niejednokrotnie nawiązujące do stylistyki horroru. Nastrój grozy oraz groteskowej śmieszności tworzą niezidentyfikowane przeciągi, dziwne hałasy, dobiegające zewsząd głosy, a także dziwne zachowanie ludzi, którzy, „nie śmiejąc zająć pustych kanap nadmiernie wysokich" ${ }^{38}$, koczują na podłodze, po czym niespodziewanie znikają bez śladu. Analogiczną sytuację obserwujemy u Kubina: „W Państwie Snu człowiek przyzwyczajał się do najnieprawdopodobniejszych rzeczy do tego stopnia, że nic już nie zdumiewało" ${ }^{39}$. Podobna jest także atmosfera, którą spowija niepokojąca woń rozkładu. Mijając bramę Państwa Snu żona bohatera profetycznie stwierdza: "Nigdy się stąd nie wydostanę!” ${ }^{40}$. Starannie wyselekcjonowani mieszkańcy tej dziwnej krainy funkcjonują niejako w próżni, stale zawieszeni pomiędzy jawą a snem, życiem a śmiercią:

Na pytania: Co się właściwie dzieje w Państwie Snu? Jak się tam żyje? musiałbym $\mathrm{w}$ odpowiedzi chyba milczeć. [...] samą istotę naszych obywateli stanowi dążenie w głąb. [...] obywatel Państwa Snu nie wierzy w nic poza snem - poza własnym snem ${ }^{41}$.

Oderwani od trosk współczesnego im świata tworzą groteskową strukturę społeczną. Pogrążeni w letargu, stale obserwowani przez absolutnego władcę Perły, niejednokrotnie zamiast pielęgnować wartości duchowe oddają się rozpuście. Można powiedzieć, iż są to wadliwe twory, które dawno już porzuciły pierwotny wzorzec, zaprojektowany przez Klausa Paterę. Samozwańczy dyktator pragnął bowiem, aby jego poddani byli ludźmi szlachetnymi, wrażliwymi, oddanymi sztuce; tymczasem stali się kimś na kształt

\footnotetext{
37 J. Speina, Bankructwo realności. Proza Brunona Schulza, Warszawa-Poznań 1974, s. 71-72.

38 B. Schulz, Sanatorium pod Klepsydra, s. 262.

39 A. Kubin, Po tamtej stronie, s. 66-67.

40 Tamże, s. 51.

41 Tamże, s. 20-21.
} 
bezwolnych manekinów. Obywatele wrzuceni w absurdalną, poddaną inercji czasoprzestrzeń mimowolnie zaakceptowali ową alogiczność, poddając się dyktaturze szaleństwa. Zdaniem Jana Gondowicza również Stanisław Ignacy Witkiewicz znał dzieła Kubina, a jego wizja mitycznej Hyrkanii przypomina Perłę:

Trudno wątpić, że z dziełem graficznym Kubina zetknąć się musiał Witkacy - jeśli nie w latach młodości, to w wieku dojrzałym za sprawą zachwytów Schulza. Pytanie brzmieć może tylko, czy znał też jedyną [...] jego powieść, summę lat kryzysu [...]. W listach do żony zwał, co prawda, imieniem Melita, które nosi tam femme fatale, pewną śmiałych obyczajów znajomą, lecz zasadnicze świadectwo to Mątwa, czyli hyrkaniczny światopoglad. Bohatera tej sztuki, malarza, nawiedza na wzór powieści szkolny kolega, który założył gdzieś w Azji ${ }^{42}$ „sztuczne królestwo" [...] - „sanatorium dla ludzi zmęczonych społecznością". Owo królestwo, Hyrkania, jest po trosze projektem, po trosze snem, w który trzeba wstąpić ${ }^{43}$.

Po tamtej stronie wypełnione jest szeregiem popularnych motywów, po które sięgali wówczas twórcy wywodzący się z niemieckiego obszaru kulturowego. Przykładowo w swojej debiutanckiej powieści z 1906 roku Niepokoje wychowanka Törlessa Robert Musil przedstawił Mefisto pod postacią szkolnego kolegi. Ten sam zabieg w Demianie zastosował Herman Hesse, z którym Kubin intensywnie korespondował. Również w Czarodziejskiej Górze Tomasza Manna mamy diabolicznego Przybysława Hippe ${ }^{44}$. Rządzący Państwem Snu Klaus Patera to także szkolny znajomy głównego protagonisty powieści. Ten mefistofeliczny, wszechwładnie panujący dyktator przywodzi na myśl surowego ojca malarza. Istnieją przesłanki, iż Kubin, kreując tego bohatera, obdarzył go pewnymi cechami Alfreda Leopolda Isidora Kubina, który początkowo sprzeciwiał się artystycznym pasjom syna. Pozostałe postaci występujące w powieści są pozbawione jakiejkolwiek tożsamości. Mieszkańcy Perły stopniowo wrastając w chorą przestrzeń zostają ubezwłasnowolnieni, tym samym tracą wszelkie pozytywne cechy. Znaczna część z nich przypomina zarysy sylwetek wyjętych wprost z obrazów Kubina ${ }^{45}$. Zdeformowani posiadacze garbów, olbrzymiego wola, narośli nosa, piękni pijacy, nieszczęśnicy

\footnotetext{
${ }^{42}$ Kubin umieścił Państwu Snu w Azji Środkowej, nieopodal Tybetu.

43 J. Gondowicz, Olśniony mrokiem, s. 41.

44 Por. tamże.

45 Chodzi o obrazy i grafiki takie jak: Madame (1900-19010, Bar (ok. 1908-1910), Włóczęga (ok. 1910), Dom wariatów (ok. 1913-1914), Noc Walpurgii (ok. 1920), Tumult (ok. 1934) czy Tańczący akrobaci (1946).
} 
skłóceni ze sobą i światem, hipochondrycy, spirytyści, zawadiacy, poszukiwacze podniet, awanturnicy, oszuści, akrobaci i mordercy, wszyscy poddani inercji niebawem znikną w mrocznej otchłani. Pochód ten widoczny jest na jednej z wczesnych prac malarza, pod znamiennym tytułem $\mathrm{Ku}$ niewiadoтети (1900-1901).

Groteskowy korowód straceńców idealnie oddawał atmosferę z początków XX wieku. Artysta w przewrotny, nieco infantylny sposób ukazał tak bliską mu aurę dekadencji oraz nieuchronny koniec cudownej belle epoque ${ }^{46}$. Możemy mówić tu także o skojarzeniach ze średniowiecznym danse macabre, a także o poddaniu się swoistej dyktaturze nie-rozumu. Michel Foucault, studiując historię szaleństwa, twierdził, iż „nie może istnieć w naszej kulturze rozum bez szaleństwa, choć racjonalne poznanie, ujmujące szaleństwo, redukuje je i rozbraja, ofiarując mu kruchy status patologicznego przypadku" ${ }^{\prime \prime 7}$. Według Foucaulta z biegiem czasu społeczeństwo Zachodu dokonało swego rodzaju gwałtu na nie-rozumie, czego symbolicznym wyznacznikiem był ów gest zerwania oraz perspektywa dystansu, niezbędna do powstania funkcjonującego obecnie języka psychiatrii ${ }^{48}$. Zdaniem francuskiego filozofa odrzucenie szaleństwa to także zanegowanie własnej oryginalności oraz wyzbycie się korzeni:

Od zarania Średniowiecza człowiek europejski pozostaje w relacji do czegoś, co niejasno nazywa Szaleństwem, Obłędem, Nierozumem [...]. W każdym razie relacja Rozum-Nierozum jest jednym z wyznaczników oryginalności kultury zachodniej; towarzyszyła jej na długo przed Hieronimem Boschem, będzie szła za nią daleko za Nietzschego i Artauda ${ }^{49}$.

Kubin poddał się szaleństwu, z niego czerpał inspirację, ono spowodowało brak barier oraz porzucenie dystansu i całkowite odrzucenie opozycji normalność-nonsens. Znamiennym tego przykładem było opatrzenie wydanej w 1926 roku autobiografii Demony i nocne zjawy obrazem Obtęd (1904), który malarz wybrał spośród dwustu innych ilustracji.

Wielu artystów zajmujących się sztuką fantastyczną balansowało na granicy szaleństwa. Jak zauważa Jan Gondowicz z problemem tym zwykle borykali się twórcy obdarzeni faustowską ciekawością, dążący do poznania granic własnej ekspresji, tacy jak Goya, van Gogh, Munch, Grandville, Čiurlionis,

\footnotetext{
46 Por. P. Szarota, Wiedeń 1913, Gdańsk 2013.

47 M. Foucault, Powiedziane, napisane. Szaleństwo i literatura, przeł. B. Banasiak, T. Komendant, Warszawa 1999, s. 10.

48 Tamże, s. 6.

49 Tamże, s. 7.
} 
Csontváry czy Wrubel ${ }^{50}$. Także główny bohater powieści Kubina, monachijski rysownik, będący niejako alter ego autora, stanowi niemal kliniczny przypadek stopniowego popadania $w$ obłęd. Bez wątpienia miało to związek $\mathrm{z}$ wszechobecnym absurdem panującym w krainie snu-agonii. W Perle mieszkańcy stale poddawani są dziwnym rytuałom, takim jak Wielki Czar Zegarowy, polegający na tym, iż o określonych godzinach wszyscy obywatele zbierali się wokół starej wieży zegarowej, następnie zaś znikali w jej wnętrzu na minutę lub dwie. Nikt z zebranych nie był w stanie wyjaśnić sensu tego swoistego obyczaju. Członkowie tej kuriozalnej, sztucznie wykreowanej społeczności codziennie doświadczają halucynacji, błądzą po ulicach tworzących rodzaj labiryntu, zupełnie jak u Kafki, którego twórczość Kubin niezwykle cenił i pragnął ilustrować. Zarówno w Zamku, jak i w Procesie bohaterowie stale zmagają się z mroczną, fatalistyczną siłą, która, przybierając postać złowrogiej machiny biurokratycznej, determinuje ich los.

Kafkę i Kubina łączy sposób postrzegania świata, który obu twórców napawał przerażeniem. Ponadto obaj nie byli w stanie przeciwstawić się surowym, drobnomieszczańskim ojcom, którzy pragnęli dla nich solidnych, "porządnych" zawodów, gwarantujących stabilizację materialną. Kafka, prowadząc podwójne życie, pisarza i urzędnika bankowego, także bliski był popadnięcia w obłęd, o czym pisał w Dziennikach. Autor Ameryki ujmował wszechświat $\mathrm{w}$ kategoriach moralnych. Przestrzeń kreowana w utworach omawianych twórców to rzeczywistość w stanie rozkładu, zmierzająca do nieuchronnej agonii. Podejmowane przez pisarzy próby budowy alternatywnego, z założenia lepszego świata kończą się niepowodzeniem, ponieważ człowiek nie jest w stanie wygrać z dławiącymi go demonami. Zarówno Kafka, jak i Kubin obficie wykorzystywali motyw negacji oraz kreowali przestrzeń składającą się z wizyjnych obrazów, tworzącą rodzaj labiryntu nie do przejścia. K., bohater Procesu, zmierzający na pierwsze przesłuchanie błądzi wśród setek korytarzy, pokojów i drzwi, powoli staje się ofiarą absurdu:

K. zwrócił się ku schodom, by dojść do pokoju rozpraw, ale znowu przystanął, gdyż oprócz tych schodów zauważył w podwórzu jeszcze trzy różne klatki schodowe, a ponadto na końcu podwórza małe przejście, które zdawało się prowadzić na jeszcze inne podwórze. Gniewało go, że nie podano mu bliżej położenia pokoju [...]. Ostatecznie wszedł jednak na schody i nasunęło mu się odległe wspomnienie sentencji Willema, że wina sama przyciąga sąd, z czego by właściwie wynikało, że lokal sądowy powinien znajdować się przy schodach, które K. przypadkowo wybrał ${ }^{51}$.

50 Por. J. Gondowicz, Olśniony mrokiem, s. 25.

51 F. Kafka, Proces, przeł. B. Schulz, Kraków 2003, s. 28-29. 
Podobnie orientację tracą postaci występujące w Po tamtej stronie. Ich niekończące się, bezcelowe wędrówki po martwym, pustym, ospałym mieście mają charakter tortur. Ulice Państwa Snu wypełnione są niezidentyfikowanymi hałasami i zaludnione przez dziwne, hermafrodytyczne byty. W państwie Klausa Patery niejednokrotnie zdarzają się fatalne, wręcz groteskowe pomyłki:

o piątej rano zadzwonił do drzwi murarz z wiadrem zaprawy i narzędziami; twierdził uparcie, że ma polecenie zamurować okna w naszym mieszkaniu. Innym razem odegrano nam późnym wieczorem serenadę: przed naszymi drzwiami koncertowała cygańska kapela. [...] Często bywało jednak jeszcze gorzej. Na przykład pewnego wieczora, o zmroku, kilku czarno ubranych ludzi wniosło do nas trumne. ${ }^{.2}$

Malarz bawił się estetyką koszmaru sennego, umiejętnie łącząc humor z makabrą. Styl jego prozy, będący udaną kompilacją ekspresjonizmu ${ }^{53}$ oraz surrealizmu, odpowiadał popularnym wówczas tendencjom literackim. Kubin zarówno w swych obrazach, jak i w prozie stworzył deliryczną, wypełnioną neurastenią przestrzeń, z premedytacją przeciwstawioną uniwersalności zachodniego ratio. Świadomy nonsens był protestem wobec dyktatury Rozumu, redukującego i rozbrajającego szaleństwo. Anormalność u tego artysty zyskała nową jakość. Znany psychiatra Antoni Kępiński, analizując osobowość malarzy cierpiących na chorobę królewską ${ }^{54}$, takich jak: J. Ensor, C.F. Hill, I. E. Josephson, zwrócił uwagę, iż za sprawą psychoz ich twórczość ewoluowała. Zdaniem lekarza to właśnie choroba „wyzwoliła u nich oryginalny talent, spętany przedtem kanonami akademickiej sztuki" ${ }^{55}$. Do grona schizofreników włączył także Alfreda Kubina, którego twórczość stanowi typowy przykład „schizofrenicznego olśnienia”:

Olśnienie schizofreniczne ukazało Alfredowi Kubinowi świat doznań psychotycznych i wyznaczyło kierunek jego dalszej twórczości plastycznej i literackiej. Odnosi się wrażenie, że bez własnych przeżyć psychotycznych nie mógłby on stworzyć tak dziwnej, groźnej i groteskowej wizji jaką dał w swoim dziele Po tamtej stronie ${ }^{56}$.

\footnotetext{
52 A. Kubin, Po tamtej stronie, s. 89-90. Snu, s. 8.

54 Inna nazwa schizofrenii.

55 A. Kępiński, Schizofrenia, Warszawa 1981, s. 82.

56 Tamże, s. 82.
}

53 Stefan Lichański uważa Po tamtej stronie za pierwszą liczącą się manifestację ekspresjonizmu, wcześniejszą niż sama nazwa, która pojawi się dopiero w wydawanym od 1910 roku przez Herwartha Waldena czasopiśmie „Der Sturm”, por. S. Lichański, Alfreda Kubina Państwo 
Z perspektywy malarza owo olśnienie miało następujący przebieg:

włóczyłem się po mieście i wszedłem wieczorem do variété, w poszukiwaniu obojętnego a hałaśliwego otoczenia, by rozładować wewnętrzny ucisk, który stawał się coraz silniejszy. I tam zdarzyło mi się coś bardzo dziwnego psychicznie, a dla mnie decydującego, co do dziś niezupełnie pojmuję [...]. Kiedy mianowicie zaczęła grać orkiestra, ujrzałem z nagła całe otoczenie jaśniej a ostrzej, jakby w innym świetle. Na twarzach obecnych dookoła dostrzegłem znienacka zaskakującą zwierzoczłowieczość. Wszystkie dźwięki stały się osobliwie obce, wyzwolone ze swej przyczyny. Brzmiało mi to niczym jakaś szydercza, stękająca, dudniąca ogólna mowa, której nie rozumiałem, lecz która zdawała się mieć najwyraźniej jakiś całkiem widmowy, wewnętrzny sens. [...] jąłem znów myśleć o rysunkach Klingera [...].

I wtem lawiną runęły na mnie wizje czarno-białych rysunków - niepodobna opisać, jakie tysięczne bogactwo podsuwała mi wyobraźnia ${ }^{57}$.

W przypadku autora Po tamtej stronie początki schizofrenii mogły w znacznej mierze wpłynąć na widoczną w powieści eksplozję treści podświadomych, które przybrały postać symbolicznych wizji ikonograficznych, jak choćby sugestywna scena z ślepym, trupio bladym, wychudzonym koniem, który, przemierzając korytarze stylizowanej na labirynt mleczarni, omal nie tratuje głównego bohatera. Biały koń zazwyczaj symbolizuje światło, jasność, dzień, czyli to, czego brakowało w Perle, z kolei koń trupio blady to zwiastun niechybnej śmierci oraz apokaliptyczny orędownik zagłady ${ }^{58}$. W Biblii czytamy: „oto koń trupio blady, a imię siedzącego na nim Śmierć, i Otchłań mu towarzyszyła" [Ap, 6:8]. Kubin niezwykle często operował biblijnym symbolizmem. W powieści na uwagę zasługują choćby opisy klęsk, które trapiły Państwo Snu. Mowa tu o inwazji dzikich zwierząt czy robactwa, które są oczywistym nawiązaniem do plag egipskich oraz do lubującego się w estetyce defektu malarstwa Odilona Redona, jednego z licznych twórców fascynujących Kubina.

Cesare Lombroso opisując schizofrenię zauważył, iż:

Choroba często rozwija - jak to widzieliśmy na przykładzie geniuszów i genialnych szaleńców - oryginalność pomysłów; widoczne jest to nawet w utworach ludzi na wpół obłąkanych, ponieważ pozbawiona hamulców ich wyobraźnia tworzy takie obrazy, jakich przeląkłby się umysł zbyt wyrachowany z obawy posądzenia o absurd i brak logiki ${ }^{59}$.

\footnotetext{
57 A. Kubin, Demony i nocne zjawy. Autobiografia, s. 270-271.

58 Por. W. Kopaliński, Stownik symboli, Warszawa 1990, s. 158.

59 C. Lombroso, Geniusz i obłakanie, s. 196.
} 
Owa chęć przekraczania granic, wzmożona refleksyjność, utrata poczucia oczywistości, wszystkie te czynniki diagnozowane są jako negatywne objawy schizofrenii. Jednakże według zwolenników nurtu-antypsychiatrycznego można mówić także o zjawisku pozytywnego, „świadomego szaleństwa". Jak zauważa Marta Drelich:

Linią graniczną odróżniającą szaleństwo świadome od choroby psychicznej jest świadomość własnych stanów bycia, w sensie zdolności doświadczania, przywoływania ich i przetwarzania na nową jakość [...]. Świadomy szaleniec podważa zastane, gdyż uznaje świat za magiczny, w którym wszystko wydarza się za pomocą słowa ${ }^{60}$.

Choroba Kubina potęgowała jego artystyczną wrażliwość, była też „motorem napędowym”, pomagającym mu tworzyć wielowarstwowe, zaczarowane światy. Końcowe partie Po tamtej stronie stanowią istne apogeum irracjonalności. Perla jawi się w nich jako ogarnięte obłędem, współczesne inferno:

Jako skutek rozpusty i użycia jęły panoszyć się w Krainie Snu przypadłości nerwowe. Znane choroby umysłowe i nerwowe, pląsawica, epilepsja, histeria, występowały obecnie jako zjawiska masowe. Niemal każdy człowiek miał tik nerwowy lub cierpiał na jakąś obsesję. Agorafobia, halucynacje, melancholia, skurcze mnożyły się zatrważająco, ale wszyscy szaleli dalej, im więcej zdarzało się najokropniejszych samobójstw, tym większe rozpasanie wśród pozostałych przy życiu ${ }^{61}$.

Kraina snu odśpiewała swą łabędzią pieśń. Dotknięci obłędem mieszkańcy, wtórując obecnemu w powieści mottu: "Na krwi szaleństwo stoi”, ulegli totalnej zagładzie. Można powiedzieć, iż Po tamtej stronie to proza w pewnym sensie profetyczna. Kubin oddał zabarwiony katastrofizmem nastrój fin de siècle'u. Powieść wydaje się zapowiedzią wszystkich późniejszych przewrotów społecznych, rebelii, krwawych rewolucji, m.in. październikowej, dyktatur oraz wszechobecnej inwigilacji. Po tamtej stronie to także dzieło fobiczne, będące radykalną manifestacją wstrętu wobec świata. W Państwie Snu mieszkańcy nie pragną posiadać dzieci, niejako nie chcąc przedłużać swojego, i tak upodlonego już, gatunku.

Kubin uznawał sztukę za „wentyl bezpieczeństwa”, twierdząc, iż artyści w swoich pracach odsłaniają duszę. Jedyna w jego dorobku powieść bywa

60 M. Kasprowicz, Nomadyczność istnienia świadomego szaleńca. Szaleństwo jako świadome wykorzenienie, w: Zjawisko szaleństwa w kulturze, red. M. Kasprowicz, S. Drelich, Toruń 2010, s. 131.

61 A. Kubin, Po tamtej stronie, s. 165. 
traktowana jako fascynujący dokument psychografii, zapis przeżyć człowieka zmagającego się z chorobą umysłową czy niezdolnego do pracy twórczej malarza. Jednakże ów schizofrenik dokonał bolesnej wiwisekcji nie tylko na samym sobie, lecz przede wszystkim na burżuazyjnym społeczeństwie początków XX wieku, które rychło miało zmierzyć się z tragicznymi skutkami swoich nietrafionych wyborów.

Podczas wielu wywiadów Kubinowi stale zadawano jedno tendencyjne pytanie: "Jak to się stało, że Pan tworzy takie rzeczy?", na co on zwykł odpowiadać:

Spodziewam się zwłaszcza, że dostatecznie wyraźnie wykazałem, iż w gruncie rzeczy ta sama siła pchała mnie $\mathrm{w}$ dzieciństwie do marzeń i głupich psikusów, potem $\mathrm{w}$ chorobę, a wreszcie ku sztuce. [...] Głęboka rezygnacja stanowi jednak już od dziesiątków lat podwalinę mego usposobienia.

[...] Chyba to jest właśnie ostateczny, właściwy sens artysty: że bezsensowi bytu narzuca on woal swojej twórczości - cienki, zakrywający woal nad otchłanią chaotycznych mocy, które dla nas są literalnie niczym w porównaniu z owym pozornym światem, przedstawiającym naszą prawdę, chociażby nią być miało jedynie złudzenie ulotne jak ulatujący czas ${ }^{62}$.

Dotychczas wszystkie wydane w Polsce edycje Po tamtej stronie zostały pozbawione sugestywnych rysunków autorstwa Kubina. W oryginale widzimy pięćdziesiąt dwie grafiki, które pomagają wczuć się w surrealistyczny klimat tej prozy. „Austriacki Goya” scalił dwie tak różne, a jednocześnie pokrewne sobie dziedziny, jakimi są malarstwo i literatura. Poddając się osobliwej terapii, przelewając słowa na papier, przełamał wielomiesięczną stagnację. Jednakże wizja, którą stworzył, nie napawa optymizmem. Iluzoryczna ucieczka bohatera ze Starego Kontynentu, a także próba budowy nowego świata oraz całkiem odmiennej tożsamości, okazuje się wyzwaniem ponad jego siły. Rozważania malarza uwidoczniają raczej egzystencjalny ból istnienia bądź rodzaj Heideggerowskiej trwogi. Paraboliczny świat Kubina rozpada się na miliony kawałków, ukazując cały bezsens ludzkich starań. Co ciekawe, po dość udanym debiucie artysta zdecydował się porzucić pisanie na rzecz malarstwa. Kubin nie odłożył pędzla, mimo iż zainteresowanie jego późniejszymi obrazami nigdy nie dorównało sławie, jaką cieszyły się w latach 20. XX wieku. Być może rzecz wyglądałaby zgoła inaczej, gdyby nawiedził go kolejny kryzys twórczy...

62 A. Kubin, Demony i nocne zjawy. Autobiografia, s. 281-282, 293. 


\section{Verbal Therapy - "Painting Told" by Alfred Kubin Summary}

The Other Side (1909) is the only novel by an Austrian painter and illustrator, Alfred Kubin. His work epitomizes the modernist concept of art synthesis. Kubin, drawing from the aesthetics of grotesque, creates an amalgam of apparently detached forms of representation, literature and painting. The Other Side uses surrealist humour and nightmarish motifs of onirism to convey the existential anxiety of fin de siècle.

Keywords: art synthesis, grotesque, literature, painting, Alfred Kubin 